\title{
Comparison of PV Rooftop Energy Production at Denpasar City Office Building
}

\author{
I Putu Eddy Saskara \\ Departement of Electrical Engineering \\ Udayana University \\ Denpasar, Indonesia \\ eddysaskara@gmail.com
}

\author{
I Nyoman Satya Kumara \\ Departement of Electrical Engineering \\ Udayana University \\ Denpasar, Indonesia \\ satya.kumara@unud.ac.id
}

\author{
I Wayan Sukerayasa \\ Departement of Electrical Engineering \\ Udayana University \\ Denpasar, Indonesia \\ sukerayasa@unud.ac.id
}

\begin{abstract}
The Indonesian government has made various targets for implementing renewable energy, one of which is the application of PV. PV rooftop in households and offices is one of the applications of $P V$ that can be applied because people can contribute to achieving national energy targets by utilizing empty spaces on the roofs of buildings. Therefore in this paper will examine how the rooftop PV system is designed and how energy is produced, as well as the factors that affect energy production. PV rooftop in Denpasar city office building has two pilot projects that can be used as research objects that will be examined how much energy potential is simulated with the HOMER application. The rooftop PV in the two pilot projects will also determine how the orientation and slope angle of the PV module are optimum. From the simulation results show the energy potential in the two pilot projects is $3 \%$ and $39 \%$ greater than the actual energy. PV rooftop on both pilot projects has $20^{\circ} \mathrm{PV}$ slope, while the calculation results show an optimal slope is $15^{\circ}$. The amount of energy produced can be affected by its less than optimal slope angle, the cleanliness of the modules that are not cleaned regularly, and the many weather conditions, rainy days and cloudy days, so that the sun is less than optimal.
\end{abstract}

Keywords - Renewable Energy, PV, PV Rooftop, Energy Production, Potential of PV Energy

\section{INTRODUCTION}

The application of Renewable Energy in Indonesia is still very small from the existing potential of $443.2 \mathrm{GW}$. The potential for renewable energy in Indonesia is only $2 \%$ of its potential. Solar energy is a renewable energy that has a huge potential energy of $207.9 \mathrm{GW}$, but the use of solar energy in Indonesia has only reached $0.04 \%$ of its potential. The development of solar power for electricity is projected at 6.5 GW in 2025 and $45 \mathrm{GW}$ in 2050 [1].

PV rooftop can help the government in fulfilling the target of solar power utilization in Indonesia, where solar panels are placed on roofs of houses or offices so that they can utilize the empty spaces on the roof to get solar energy that can be converted into electrical energy. Urban communities in Indonesia also have quite good characteristics in the use of PV such as purchasing power, level of education, and understanding of the environment and its protection. In Indonesia there is also the availability of PV components to support the PV rooftop, the constraints of the slow progress of this development because the main components of PV are solar panels that still get these products from other countries [2]. The government has also made regulations to support the development of $\mathrm{PV}$ in Indonesia for the realization of renewable energy targets and attract the public in utilizing rooftop PV. PLN's Directors Regulation No. 0733.K / DIR / 2013 allows people to sell electrical energy produced by rooftop PV to the State Electricity Company (PLN) [3].

PV in Indonesia will be built a lot, especially PV rooftop in achieving the $6.5 \mathrm{GW}$ target in 2025. Therefore, PV rooftop information is needed for people who will install PV rooftop so they can contribute in the development of PV. These information are the technical design of PV, Potential energy production of $\mathrm{PV}$, energy production from installed $\mathrm{PV}$, and factors that affect PV energy production. This information is expected to help people to contribute in building PV at home or in their offices.

PLN Distribusi Bali in the city of Denpasar has installed two PV rooftop that can be used as pilot projects, that is in the PLN Distribusi Bali building (Building \# 1) and in the PLN Area Bali Selatan building (Building \# 2). Building \# 1 is installed with a $30 \mathrm{~kW}$ rooftop PV with a number of 120 units of modules, each module has an output power of $250 \mathrm{~W}$, inverter used is two units with a capacity of each inverter of $20 \mathrm{~kW}$. In Building \# 2 there is a $10 \mathrm{~kW}$ rooftop PV with a number of 38 unit modules, each module has an output power of $265 \mathrm{~W}$, with one inverter unit used with a capacity of $10 \mathrm{~kW}$. Both pilot projects do not use battery backup and directly connected to the grid.

This study will examine both the rooftop PV pilot projects in Building \# 1 and Building \# 2 by simulating the installed PV to get the energy potential that is simulated with the HOMER software. The study also determines the orientation and slope angle of the PV to be analyzed to find out about the PV rooftop technical design, the PV rooftop potential energy produced, energy production of installed PV rooftop, and factors that affect the PV rooftop energy production. These information about PV rooftop is not available yet in Indonesia even though this information is very important to be known by the Indonesian people. This information is also expected to attract that people to participate in installing rooftop PV for the realization of the national energy that has been targeted.

\section{METHODOLOGY}

The data used in this study are documentation, environmental conditions, monitoring data recorded on PV installed in Building \# 1 and Building \# 2, single line diagrams, location data and weather data from the Climatology and Geophysics Meteorology Agency (BMKG). 
The maximum efficiency of the solar panel will increase if the angle of sunlight is always at $90^{\circ}$ to the panel surface. But in reality the incident of solar radiation varies based on latitude and declination of the sun for a year. In fact the Earth's rotational axis has a slope of about $23.45^{\circ}$ to the plane of the Earth's orbit by the sun, at certain latitudes high from the sun in the sky varies every day. To find out the maximum height of the sun (in degrees) when the sun reaches the sky $(\alpha)$, it is easy to use the following formula [4]:

$$
\begin{gathered}
\alpha=90^{\circ}-\text { lat }+\delta(N \text { hemisphere }) \\
\alpha=90^{\circ}+\text { lat }-\delta(S \text { hemisphere })
\end{gathered}
$$

Where, Lat is the latitude (latitude) of the PV location that is installed (in degrees) and $\delta$ is the angle of the sun's declination $\left(23.45^{\circ}\right)$.

If the angular angle of the maximum height of the sun $(\alpha)$ is known, then the slope of the PV module $(\beta)$ can also be known. But it is not enough to just know $\alpha$ to determine the optimal orientation of the PV module, while the angle that must be formed by the PV module against the earth's surface $(\beta)$, can be obtained by:

$$
\beta=90^{\circ}-\alpha
$$

To get potential energy production in PV installations can be done with a professional simulation program [5]. HOMER is software that is used to help modeling of an electric power system by using a variety of renewable resources [6].

$\mathrm{PV}$ orientation in the case of PV rooftop can be obtained by using the compass application on a smartphone that provides a map from Google so that we can see the image of the upper part of the building from the Google satellite and get the results in which direction the roof of the building is facing [7].

The roof orientation is obtained by entering the address where the building was built on Google Maps, after that there will be a compass image that shows the cardinal direction of Google Maps, and there is an axis in the center of the compass that shows the orientation where the observer / building is facing, after that place the axis on the application to the axis of the building that wants to know its orientation, after that we get in the direction of the orientation of the building.

The slope angle for rooftop PV, especially the pitched roof usually tends to follow the slope of the roof, in this case to find out how the slope of the PV can be measured by using a smartphone application that can do angle measurements equipped with angle measurement features via camera or image such as the Pitch Gauge application, Angle Meter Pro, Smart Protactor [8]. The slope measurement is done by calibrating the smartphone where the $0^{\circ}$ angle is parallel to the roof base (Run / Span), then the smartphone is tilted to follow the slope of the roof captured by the camera and the measurement results are displayed on the screen.

Research on the production of PV rooftop energy in Building \# 1 and PV rooftop in Building \# 2 is carried out with the following steps:

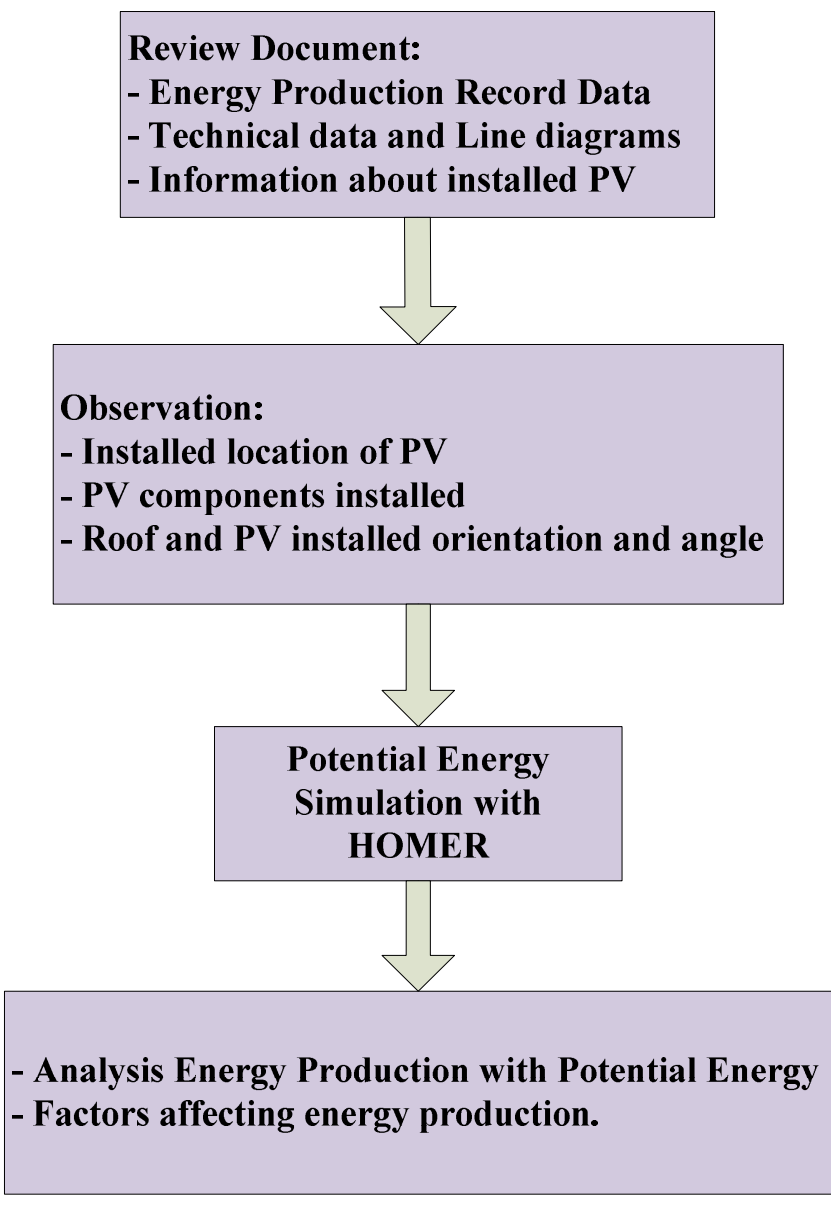

Figure 1. Research Diagram

\section{RESULT AND DISCUSSION}

\section{A. Technical Design PV Rooftop Building \#1}

Building \#1 located at J1. Letda Tantular No.1, Dangin Puri Klod, Denpasar Timur, Kota Denpasar, Bali.

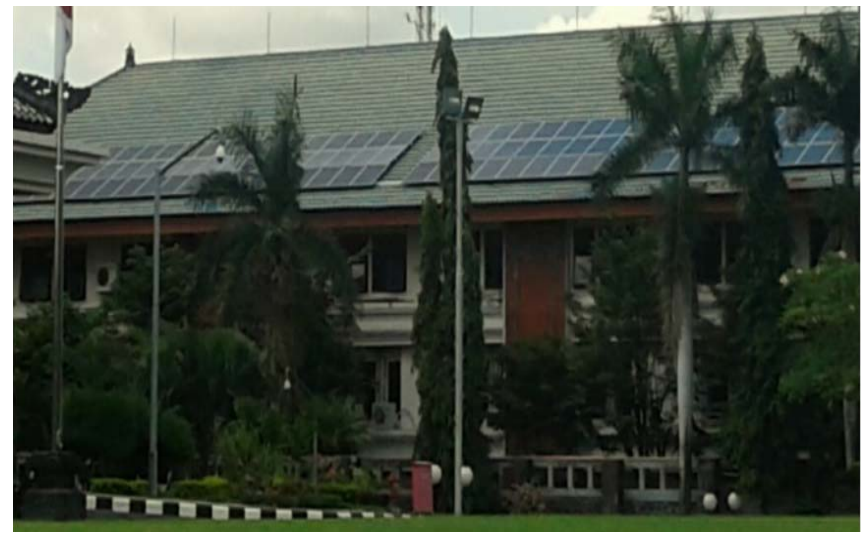

Figure 2. PV Rooftop at Building \#1

Building \# 1 installed PV rooftop with a capacity of 30kW, installed since May 2017 and starting operation in June 2017. PV rooftop Building \# 1 is an on-grid PV that supplies electrical energy to the office and gets additional electricity supply from the grid if the PV is not enough to fill the load. 


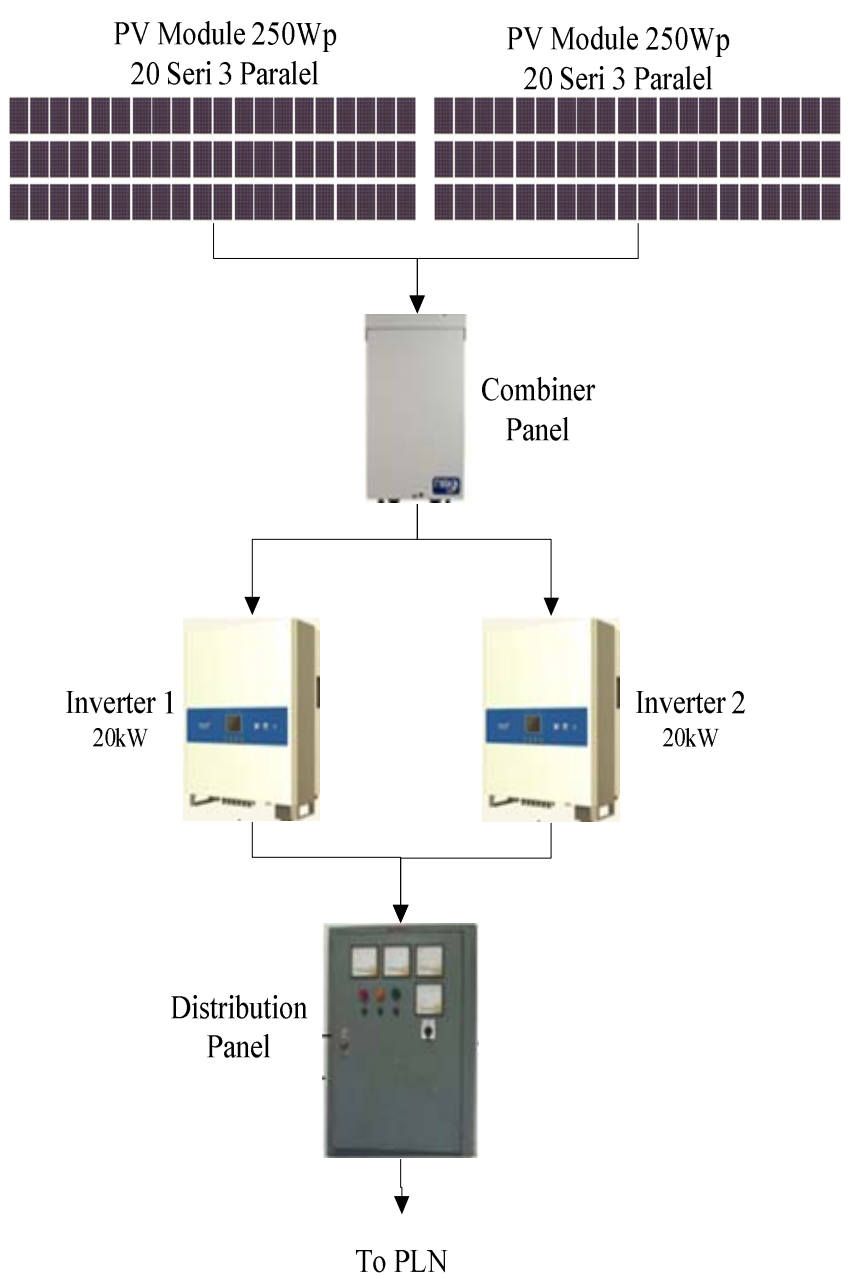

Figure 3. Line Diagram PV Rooftop at Building \#1

PV rooftop in Building \# 1 is a PV with the system connected to the grid (On-Grid). PV rooftop in Building \# 1 has a power capacity of $30 \mathrm{kWp}$, which is produced from 120 Perlight PLM-260p-60 series PV modules with the power of each PV module is $250 \mathrm{Wp}$. The entire PV module is divided into 2 arrays, each array consisting of 60 modules connected in series and parallel. Electrical energy produced by one group of PV arrays will be distributed first through the combiner panel. After going through the combiner panel, electrical energy in the form of direct current will be converted by the SPI20K-B Series Kehua Tech inverter into alternating current to pass through the AC distribution panel. The AC distribution panel will distribute the PV energy to the office load $(690 \mathrm{kVA})$ which will get a back-up from the grid if the energy produced by PV is not enough to fill the office load.

\section{B. Technical Design PV Rooftop Building \#2}

Building \# 2 located at Jl. P.B. Sudirman No.2, Dauh Puri, Denpasar Barat, Kota Denpasar, Bali. Building \# 2 is installed with PV rooftop with a capacity of $10 \mathrm{~kW}$, installed since the beginning of January 2017 and starts operating in mid-January 2017. PV rooftop Building \# 2 is an on-grid PV that supplies electrical energy to the office and gets additional electricity supply from the grid if PV is not enough to fill the load.

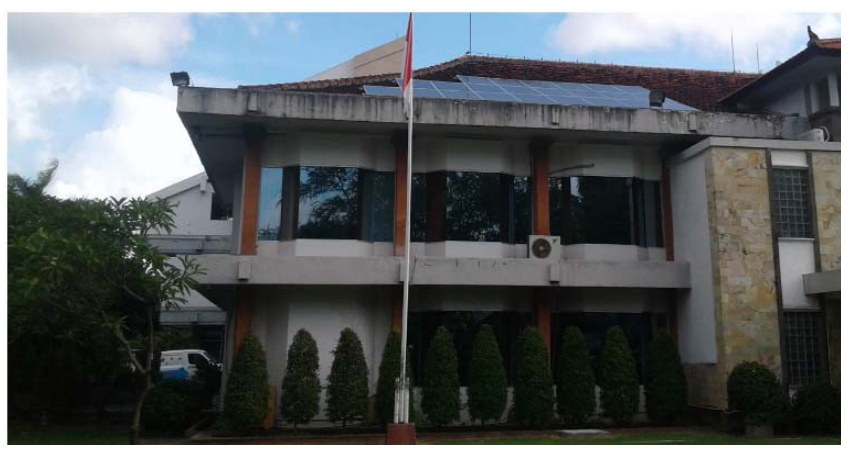

Figure 4. PV Rooftop at Building \#2
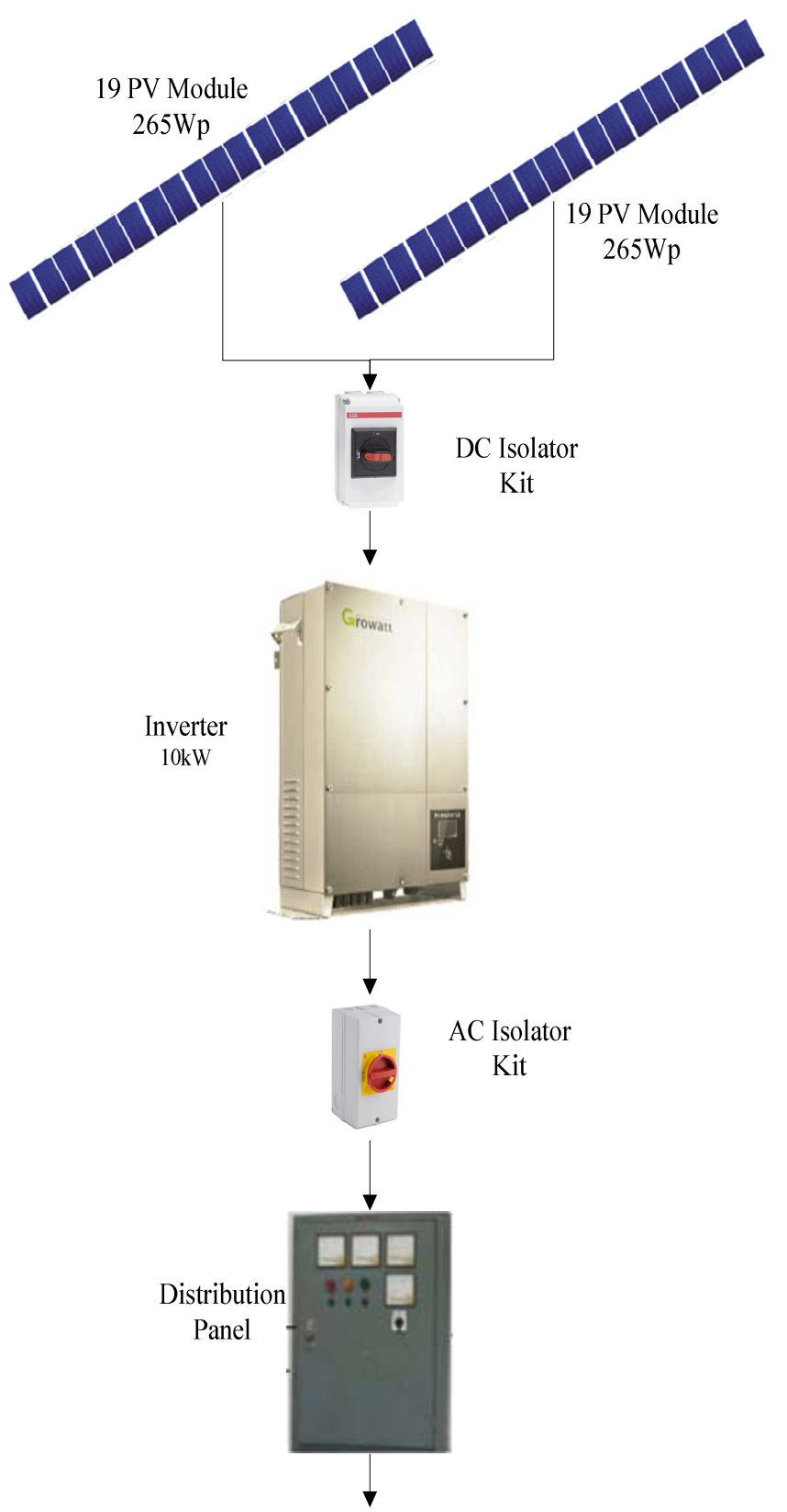

To PLN

Figure 5. Line Diagram PV rooftop at Building \#2 
$\mathrm{PV}$ rooftop in Building \# 2 is a PV with a grid-connected system (On-Grid). PV rooftop in Building \# 2 has a power capacity of $10 \mathrm{kWp}$, generated from 38 Canadian Solar CS6P-265P-SD PV modules with the power of each PV module is $265 \mathrm{Wp}$. The entire PV module is divided into 2 arrays, each array consisting of 19 modules connected in series.

The electrical energy produced by a group of PV arrays will be distributed first through to the DC isolator kit. After going through the DC isolator kit, the electrical energy in the form of direct current will be converted by the Growatt 10000UE inverter into an alternating current to the $\mathrm{AC}$ isolator kit to pass the AC distribution panel, which will then be distributed to the office load (197 kVA) which will get a back-up from the grid if PV cannot fill the load.

The orientation of PV in both locations is facing north, because both locations are located in the southern latitude. The orientation of the PV module follows the roof orientation obtained with the GPS Compass Navigator application.

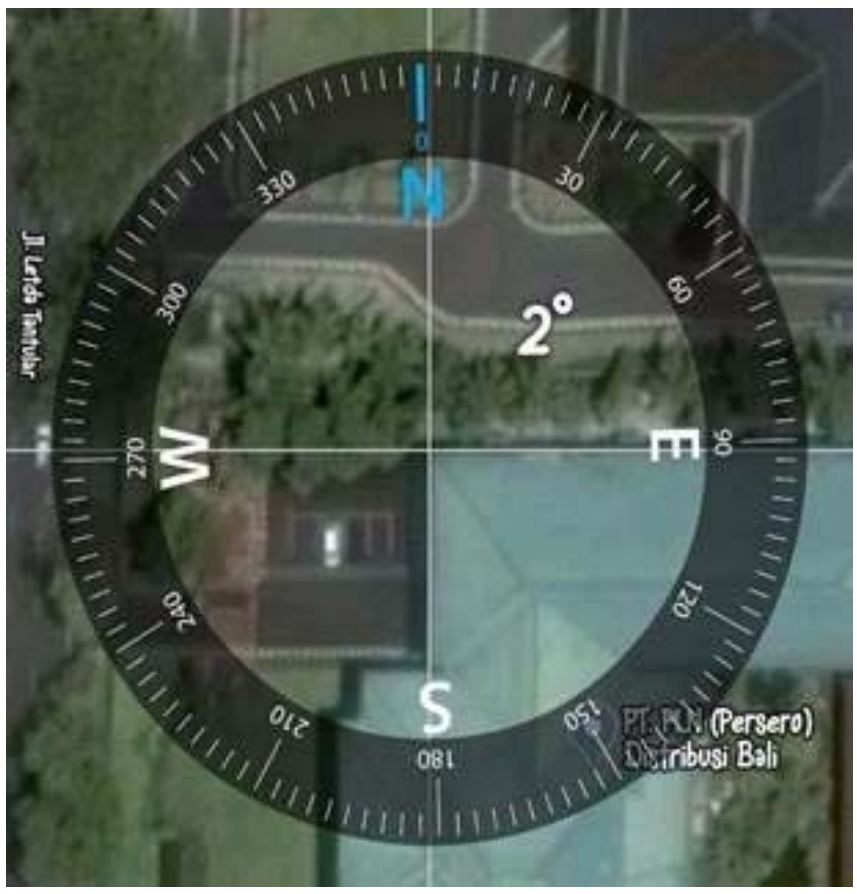

Figure 6. Determine Roof / PV Orientation with GPS Compass Navigator

The slope of PV module $(\beta)$ in both locations is the same because the latitude of the two locations tends to be the same, namely 8.66 south latitude and the slope of PV is determined by looking for the maximum sun height in degrees $(\alpha)$ using:

$$
\begin{aligned}
\alpha & =90^{\circ}+\text { lat }-\delta \\
& =90^{\circ}+8.66^{\circ}-23.45^{\circ} \\
& =75.21^{\circ}
\end{aligned}
$$

While the angle that must be formed by the PV module against the earth's surface/the slope of PV $(\beta)$, can be obtained as follows:

$$
\begin{aligned}
\beta & =90^{\circ}-\alpha \\
& =90^{\circ}-75.21^{\circ} \\
& =14.79^{\circ}=15^{\circ}
\end{aligned}
$$

So, the optimal PV module slope is $15^{\circ}$, the slope of PV in both locations is not optimal, which is $20^{\circ}$ obtained from the Angle Meter Pro application.

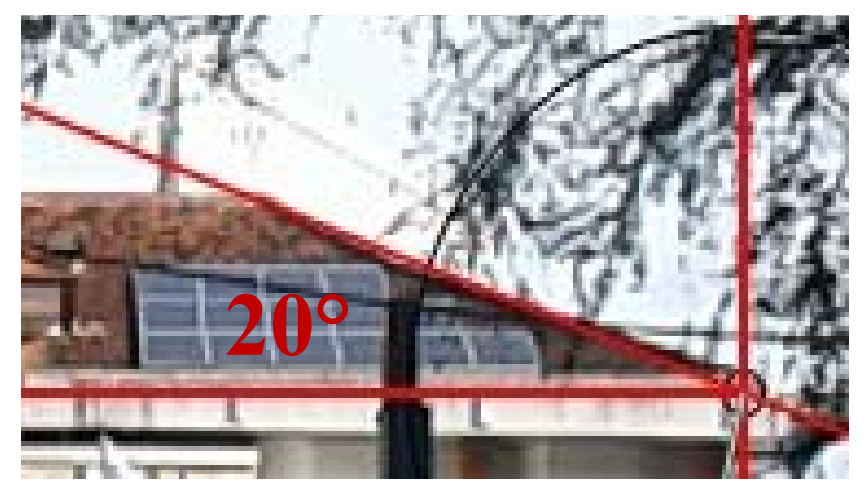

Figure 7. Determining Roof / PV Slope with Angle Meter Pro

\section{Energy Simulation}

Potential of PV rooftop energy production in both PLN buildings is simulated using the HOMER application. There are three scenarios in this simulation, the first without using a solar tracker with the slope angle of the PV module according to the installed PV. Second, simulating the installed PV with vertical axis continuous adjustment solar tracker where the axis of PV movement is in the north and south so that PV moves from east to west, selection of this single axis vertical type solar tracker because this type is the most commonly used type and produces more energy from other single axis types [9]. Third, Solar tracker two axis where PV moves freely from east to west and also north to south according to where the sun comes from. So that the rooftop PV simulation results in Building \#1 and Building \#2 on the HOMER can be seen as follows:

TABLE I. RESULT OF HOMER PV BUILDING \#2 SIMULATION

\begin{tabular}{|c|c|c|c|}
\hline Month & $\begin{array}{c}\text { No Tracking } \\
(\mathrm{kWh})\end{array}$ & $\begin{array}{c}\text { Single Axis } \\
(\mathrm{kWh})\end{array}$ & $\begin{array}{c}\text { Two Axis } \\
(\mathrm{kWh})\end{array}$ \\
\hline Jan & 1,090 & 1,436 & 1,527 \\
\hline Feb & 1,058 & 1,308 & 1,363 \\
\hline Mar & 1,328 & 1,569 & 1,682 \\
\hline Apr & 1,381 & 1,534 & 1,686 \\
\hline May & 1,474 & 1,577 & 1,823 \\
\hline Jun & 1,357 & 1,423 & 1,670 \\
\hline Jul & 1,367 & 1,445 & 1,667 \\
\hline Aug & 1,453 & 1,589 & 1,813 \\
\hline Sep & 1,458 & 1,699 & 1,894 \\
\hline Oct & 1,461 & 1,791 & 1,962 \\
\hline Nov & 1,217 & 1,589 & 1,757 \\
\hline Dec & 1,153 & 1,530 & 1,652 \\
\hline $\begin{array}{c}\text { Total } \\
\text { (kWh) }\end{array}$ & $\mathbf{1 5 , 7 9 9}$ & $\mathbf{1 8 , 4 9 1}$ & $\mathbf{2 0 , 4 9 7}$ \\
\hline
\end{tabular}

Potential of PV energy production Building \#2 for a year from HOMER simulation results is $15,799 \mathrm{kWh} /$ year. PV energy potential with single axis solar tracking is 18,491 $\mathrm{kWh} /$ year which is $17.0 \%$ greater than the energy potential without solar tracker. PV energy potential with two axis solar tracking is $20,497 \mathrm{kWh}$ /year which is $29.7 \%$ greater than energy potential without solar tracker. 
TABLE II. RESULT OF HOMER PV BUILDING \#1 SIMULATION

\begin{tabular}{|c|c|c|c|}
\hline Month & $\begin{array}{c}\text { No Tracking } \\
(\mathrm{kWh})\end{array}$ & $\begin{array}{c}\text { Single Axis } \\
(\mathrm{kWh})\end{array}$ & $\begin{array}{c}\text { Two Axis } \\
(\mathrm{kWh})\end{array}$ \\
\hline Jan & 3,267 & 4,303 & 4,576 \\
\hline Feb & 3,172 & 3,921 & 4,083 \\
\hline Mar & 3,981 & 4,701 & 5,041 \\
\hline Apr & 4,140 & 4,598 & 5,053 \\
\hline May & 4,418 & 4,726 & 5,461 \\
\hline Jun & 4,068 & 4,266 & 5,003 \\
\hline Jul & 4,096 & 4,331 & 4,996 \\
\hline Aug & 4,354 & 4,760 & 5,433 \\
\hline Sep & 4,369 & 5,090 & 5,675 \\
\hline Oct & 4,379 & 5,368 & 5,878 \\
\hline Nov & 3,646 & 4,761 & 5,263 \\
\hline Dec & 3,457 & 4,586 & 4,950 \\
\hline $\begin{array}{c}\text { Total } \\
\text { (kWh) }\end{array}$ & $\mathbf{4 7 , 3 4 7}$ & $\mathbf{5 5 , 4 1 3}$ & $\mathbf{5 5 , 4 1 3}$ \\
\hline
\end{tabular}

Potential of PV energy production Building \#1 for a year from HOMER simulation results is $47,347 \mathrm{kWh} /$ year. PV energy potential with single axis solar tracking is 55,413 $\mathrm{kWh} /$ year which is $17.0 \%$ greater than the energy potential without solar tracker. PV energy potential with two axis solar tracking is $55,413 \mathrm{kWh} /$ year which is $29.7 \%$ greater than energy potential without solar tracker.

\section{Actual Energy Production}

PV rooftop energy production in Building \# 2 is obtained from May 2017 to April 2018 with actual energy production data as follows:

TABLE III. ACTUAL ENERGY PRODUCTION PV BUILDING \#2

\begin{tabular}{|c|c|c|}
\hline Year & Month & Energy Production (kWh) \\
\hline \multirow{8}{*}{$\frac{\sqrt{0}}{\delta}$} & May & 1,519 \\
\hline & Jun & 1,275 \\
\hline & Jul & 1,297 \\
\hline & Aug & 1,359 \\
\hline & Sep & 1,458 \\
\hline & Oct & 1,342 \\
\hline & Nov & 994 \\
\hline & Dec & 992 \\
\hline \multirow{4}{*}{$\stackrel{\infty}{\stackrel{\infty}{\sim}}$} & Jan & 1,002 \\
\hline & Feb & 1,196 \\
\hline & Mar & 1,353 \\
\hline & Apr & 1,589 \\
\hline \multicolumn{2}{|c|}{ Total } & 15,375 \\
\hline
\end{tabular}

The largest PV energy production is in April 2018 and the smallest PV energy production in December 2017, with an average energy production in one year is 1,281 $\mathrm{kWh} /$ month. The energy produced by PV supplies to office loads by $6 \%$ where the total building \# 2 load in one year is $254,177.2 \mathrm{kWh}$ with the energy produced by PV for one year is $15,375.4 \mathrm{kWh}$, the need for loads not yet supplied by PV will be supplied by the PLN grid.

PV rooftop energy production in Building \# 1 obtained from June 2017 to May 2018 with actual energy production data as follows:
TABLE IV. ACTUAL ENERGY PRODUCTION PV BUILDING \#1

\begin{tabular}{|c|c|c|}
\hline Year & Month & Energy Production (kWh) \\
\hline \multirow{4}{*}{$*$} & Jun & 796 \\
\cline { 2 - 3 } & Jul & 2,438 \\
\cline { 2 - 3 } & Aug & 3,984 \\
\cline { 2 - 3 } & Sep & 4,333 \\
\cline { 2 - 3 } & Oct & 2,968 \\
\cline { 2 - 3 } & Nov & 2,009 \\
\cline { 2 - 3 } & Dec & 1,381 \\
\hline \multirow{4}{*}{$\underset{\sim}{*}$} & Jan & 1,446 \\
\cline { 2 - 3 } & Feb & 1,481 \\
\cline { 2 - 3 } & Mar & 1,661 \\
\cline { 2 - 3 } & Apr & 2,010 \\
\cline { 2 - 3 } & May & 4,449 \\
\hline \multicolumn{2}{|c|}{ Total } & 28,955 \\
\hline
\end{tabular}

The largest PV energy production is in May 2018 and the smallest PV energy production in June 2017, with an average annual energy production of 2,413 $\mathrm{kWh} /$ month. Energy produced by PV supplies 3\% of office expenses for a year from June 2017 to May 2018 where the total load of Building \# 1 in that year is $879,095.31 \mathrm{kWh}$ with the energy produced by PV for the year is $28,955.31 \mathrm{kWh}$, the need for loads not yet supplied by PV will be supplied by the PLN grid.

\section{E. Energy Production Analysis}

Comparison of actual energy production with energy production simulation results or potential energy production in Building \# 2 is indicated by the following diagram:

\section{Energy Production PV Building \#2}

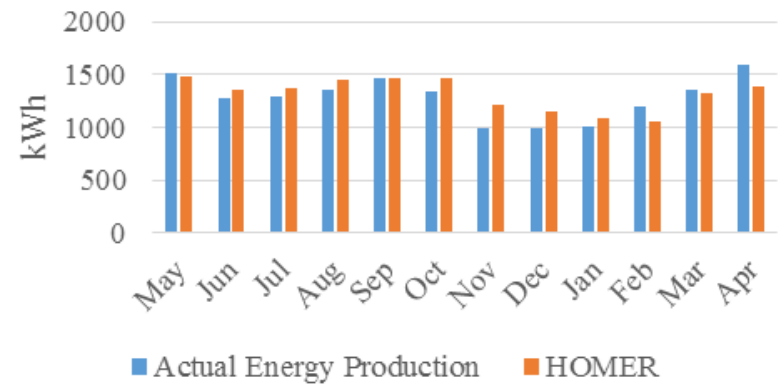

Figure 8. Diagram of Actual Energy Production and Potential Energy with HOMER Simulation

Comparison of Building \#2 potential energy production / simulation results with Building \# 2 energy production is $3 \%$. A small difference in potential energy production with actual energy production in Building \# 2 can occur because $\mathrm{PV}$ in Building \# 2 there is no equipment damage that occurs in the 1 year, except that there is no maintenance and no module cleanliness attention. Energy production in April was greater than its potential because in April 2018 there was only 2 rainy days and no cloudy days so that in April 2018 PV had a long duration of sunlight. Energy production in November and December has a considerable difference from its energy potential, this is because in November and December 2017 there are many rainy days and cloudy days 
so that the PV surface gets less sunlight. Below is a table of the number of rainy days and cloudy days below:

TABLE V. DENPASAR CITY WEATHER DATA

\begin{tabular}{|c|c|c|c|c|}
\hline Year & Month & $\begin{array}{c}\text { Rainy } \\
\text { (days) }\end{array}$ & $\begin{array}{c}\text { Cloudy } \\
\text { (days) }\end{array}$ & $\begin{array}{c}\text { Sunshine } \\
\text { Duration (Hour) }\end{array}$ \\
\hline \multirow{4}{*}{$\approx$} & May & 9 & 4 & 6.84 \\
\cline { 2 - 5 } & Jun & 11 & 6 & 6.48 \\
\cline { 2 - 5 } & Jul & 10 & 15 & 6.24 \\
\cline { 2 - 5 } & Aug & 2 & 8 & 7.2 \\
\cline { 2 - 5 } & Sep & 4 & 5 & 7.68 \\
\cline { 2 - 5 } & Oct & 15 & 4 & 7.68 \\
\cline { 2 - 5 } & Nov & 22 & 2 & 3.48 \\
\cline { 2 - 5 }$\infty$ & Dec & 22 & 4 & 3.96 \\
\hline \multirow{5}{*}{} & Jan & 25 & 3 & 3.6 \\
\cline { 2 - 5 } & Feb & 20 & 2 & 6.36 \\
\cline { 2 - 5 } & Mar & 13 & 4 & 6.48 \\
\cline { 2 - 5 } & Apr & 2 & 0 & 8.16 \\
\cline { 2 - 5 } & May & 3 & 0 & 8.04 \\
\hline
\end{tabular}

\section{Energy Production PV Building \#2 and}

Sunshine Duration at Denpasar

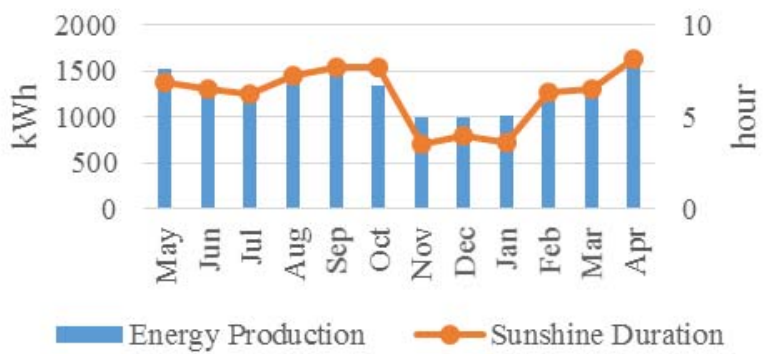

Figure 9. Diagrom of PV Energy Production Building \# 2 with Sunshine Duration

In the diagram above, a comparison of the actual PV rooftop energy production Building \# 2 with sunshine duration in Denpasar City has the same graphical pattern which can be concluded that the PV rooftop energy production Building \# 2 is directly equivalent to the duration of sunshine in Denpasar city at the same time.

Comparison of actual energy production with energy production simulation results or potential energy production in Building \# 1 is indicated by the following diagram:

\section{Energy Production PV Building \#1}

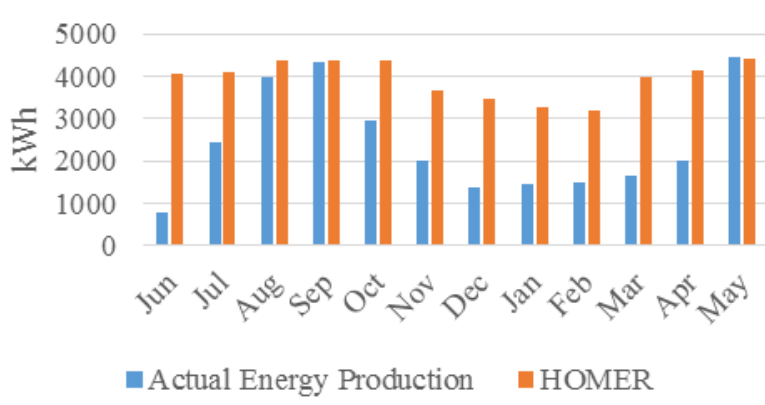

Figure 10. Diagram of Actual Energy Production and Potential Energy with HOMER Simulation
Energy Production PV Building \#1 and Sunshine Duration at Denpasar

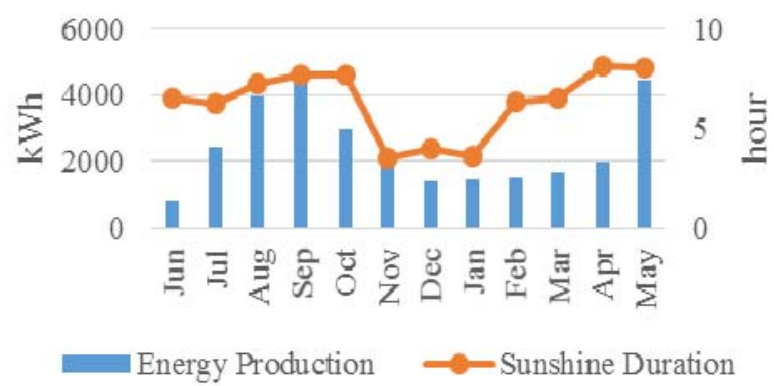

Figure 11. Diagrom of PV Energy Production Building \# 1 with Sunshine Duration

Energy production PV Building \# 1 has a significant difference from its energy production with its energy potential which is $39 \%$, this is because in October 2017 to April 2018 there was damage to one of the inverters that got a breakdown in that inverter's fuse, which caused a reduction in PV energy production of Building \#1 from October 2017. In June and July 2017 the energy production of PV Building \# 1 differs greatly from its potential because there are still component adjustments in the synchronization settings on inverters when paralleled, which is PV rooftop in the Office Building \# 1 is installed since the end of May 2017. Building \# 1 also does not carry out routine cleaning treatments.

TABLE VI. EFFECT OF PV SLOPE VARIATIONS ON ENERGY PRODUCTION IN BUILDING \#2

\begin{tabular}{|c|c|c|c|}
\hline $\begin{array}{c}\text { PV } \\
\text { Slope }\end{array}$ & $\begin{array}{c}\text { Energy } \\
\text { Simulation } \\
\text { Building \#2 }\end{array}$ & $\begin{array}{c}\text { The energy of } \\
\text { each slope is } \\
\text { divided by } \\
\text { optimal energy }\end{array}$ & Notes \\
\hline $0^{\circ}$ & 15,823 & 0.9905 & Horizontal \\
\hline $5^{\circ}$ & 15,941 & 0.9979 & $<$ Optimal \\
\hline $15^{\circ}$ & 15,974 & 1.0000 & Optimal \\
\hline $20^{\circ}$ & 15,799 & 0.9890 & Installed \\
\hline $25^{\circ}$ & 15,590 & 0.9760 & $>$ Optimal \\
\hline $30^{\circ}$ & 15,304 & 0.9581 & $>$ Optimal \\
\hline $45^{\circ}$ & 14,016 & 0.8774 & $>$ Optimal \\
\hline
\end{tabular}

TABLE VII. EFFECT OF PV SLOPE VARIATIONS ON ENERGY PRODUCTION IN BUILDING \#1

\begin{tabular}{|c|c|c|c|}
\hline $\begin{array}{c}\text { PV } \\
\text { Slope }\end{array}$ & $\begin{array}{c}\text { Energy } \\
\text { Simulation } \\
\text { Building \#1 }\end{array}$ & $\begin{array}{c}\text { The energy of } \\
\text { each slope is } \\
\text { divided by } \\
\text { optimal energy }\end{array}$ & Notes \\
\hline $0^{\circ}$ & 47,421 & 0.9906 & Horizontal \\
\hline $5^{\circ}$ & 47,774 & 0.9979 & $<$ Optimal \\
\hline $15^{\circ}$ & 47,873 & 1.0000 & Optimal \\
\hline $20^{\circ}$ & 47,347 & 0.9890 & Installed \\
\hline $25^{\circ}$ & 46,723 & 0.9760 & $>$ Optimal \\
\hline $30^{\circ}$ & 45,866 & 0.9581 & $>$ Optimal \\
\hline $45^{\circ}$ & 42,010 & 0.8775 & $>$ Optimal \\
\hline
\end{tabular}


From the table above we can see the effect of the slope angle of PV where energy production at the optimal PV slope is greater than the energy production at the installed PV slope angle, which is $175 \mathrm{kWh}$ for Building \# 2 and $526 \mathrm{kWh}$ for Building \# 1 . The PV slope of the module Building \# 1 and Building \# 2 is not the same as the slope of the calculation because the installed PV slope follows the slope of the building roof which causes no optimal solar irradiation and reduced energy produced by PV. HOMER can simulate the effect of the PV angle that is not optimal for energy production as shown by the table above.

\section{CONCLUSION}

The PV rooftop in Building \# 1 and Building \# 2 has a certified rooftop PV component and an optimal module orientation which is facing north, but the PV module slope that follows the roof slope angle is $20^{\circ}$ where it is not the same as the optimal PV module slope calculation is $15^{\circ}$. This not optimal slope of PV causes the PV surface to not get effective sunlight and affects the PV energy production. If the slope angle of PV is smaller or bigger than the optimal slope angle, then smaller energy can produced.

PV energy production in Building \# 2 is not much different with its energy potential is $3 \%$. PV energy production in Building \# 1 is far different from its energy potential is $39 \%$, this is due to damaged components, not optimal PV slope, module cleanliness and weather.

The factors that affect energy production in Building \# 2 are the less optimal module angle so that it does not optimal to get sunlight, module cleanliness can also cause the module not optimal to get sunlight, and weather which are plenty of rainy days and cloudy days so that it does not optimal to get sunlight. The factors that affect energy production in
Building \# 1 are damage to one of the inverters that got a breakdown in that inverter's fuse, there are still component adjustments in the synchronization settings on inverters when paralleled, the module's slope angle is less than optimal where the slope angle follows the slope angle the roof is $20^{\circ}$ while the optimal angle is $15^{\circ}$ so the module is less optimal in getting sunlight, the cleanliness of the module can cause obstruction of the module to get sunlight, and the weather where there are plenty of rainy days and cloudy days so that it lacks of sunlight.

\section{REFERENCES}

[1] Peraturan Presiden Republik Indonesia Nomor 22 Tahun 2017 Tentang Rencana Umum Energi Nasional.

[2] Kumara, N.S., "Pembangkit Listrik Tenaga Surya Skala Rumah Tangga Urban dan Ketersediaannya di Indonesia". Majalah Ilmiah Teknologi Elektro. Vol. 9 No.1, 2010.

[3] Peraturan Direksi PT PLN No. 0733.K/DIR/2013 Tentang Pemanfaatan Energi Listrik Dari Fotovoltaik Oleh Pelanggan PT PLN (Persero)

[4] ABB, Technical Application Papers No. 10 Photovoltaic Plants. Bergamo: ABB SACE, 2010.

[5] Mertens, K., Photovoltaics : fundamentals, technology and practice. United Kingdom: Wiley, 2014.

[6] HOMER Pro version 3. 11 user manual, Homerenergy, Colorado, USA, 2018.

[7] Free Solar Panels. (2018). How To Find Out What Direction Your Roof Is Facing [Online]. Available: http://www.freesolarpanelsuk.co.uk/how-to-find-out-what-directionyour-roof-is-facing.php.

[8] InterNACHI. (2018). Measuring Roof Slope and Pitch [Online]. Available: https://www.nachi.org/roof-slope-pitch.htm.

[9] Hassan ,Z. A. G., Anjali, A., Makbul,A.M.R., "Optimal design and analysis of grid-connected photovoltaic under different tracking systems using HOMER". Energy Conversion and Management 155 (2018) 42-57, 2017. 